\title{
A Critical Literature Review On The Link Between Multinational Enterprises Presence, Absorptive Capacity And Competitive Advantage Of Firms
}

\author{
Wanjere Munuhe Dishon
}

Department of Business Administration and Management

School of Business and Economics, Masinde Muliro University of Science \& Technology, Kenya.

\author{
Dr. John Yabs \\ Department of Business Administration, School of Business \\ University of Nairobi, Kenya.
}

\begin{abstract}
Scholars seem to agree on the importance of the local activity of foreign MNEs for country's development, but opinions differ widely concerning their impact. As the government work out policies to improve Foreign Direct Investment, questions that need to be answered include how Multinational Enterprises affects the competitiveness of the local domestic enterprise. This paper presents a critical review of literature on the link between the presence of Multinational Enterprises, absorptive capacity and the competitiveness of domestic firms. A number of theories have been presented and empirical literature reviewed on the key constructs of the study. A conceptual model on the relationship was developed showing the link between MNEs presence, absorptive capacity and competitive advantage. Absorptive capacity was conceptualized as an intervening variable and was operationalised as research and development activities, internal and external organization of innovation and quality of human capital. This relationship was conceptualized as moderated by distance which was operationalised as culture, physical location and institutional difference. The competitiveness for the purpose of this study was conceptualized to mean productivity and innovation advantage. The reviewed literature confirms the fact that MNEs presence act as a source of knowledge which is transferred to domestic firms which in turn achieve competitive advantage. This transfer is made possible by the existence of the absorptive capacity among the firms. For that reason we emphasize that FDI related policy needs to be concerned not only with attracting MNEs, but also with securing effective benefits. In other words, policy makers must consider all factors that hinders knowledge transfer to the domestic firms like the absorptive capacity. The reviewed literature support the argument that the greater a firm's exposure to knowledge sources, the greater the firm will acquire the competitive advantage. Like all research, the present study has limitations mainly the lack of primary data as it was more of a conceptual study.
\end{abstract}

\section{INTRODUCTION}

Scholars in strategy field are concerned fundamentally with explaining differential firm performance (Rumelt, Schendel and Teece 1991). They have identified two sources of competitive advantage. 
The first is the industry structure view associated with Porters (1980) that suggest that supernormal returns are primarily a function of a firm's membership in an industry with favorable structural characteristics.

The second view is the Resource Based View (RBV) of the firm that argues that differential firm performance is fundamentally due to firm heterogeneity rather than industry structure. Firms that are able to accumulate resource capabilities that are rare and difficult to imitate are able to achieve competitive advantage over competing firms (Barney, 1991).

The resource based view (RBV) is a model that sees resources as key to superior firm performance. This approach to achieving competitive advantage emerged in 1980s and 1990s after the major work published by Wernerfelt (1984) the resource based view of a firm and Prahald and Hamel (1990) the core competences of the corporation. The resource based theory present an argument that knowledge is one of the most important resources a firm can manage. Knowledge can be considered like the biggest strategic resource of a company, and the dexterity to obtain it, and use it as the biggest capacity to maintain a competitive advantage (Cohen and Levinthal, 1990). The knowledge based competitive advantages are difficult to imitate and socially embedded in organizations. Nonaka (1994) argued that organization that are able to stimulate and improve the knowledge of their human capital, are much more prepared to face today's rapid changes and innovate in the domain where they decide to invest and compete.

Scholars seem to agree on the importance of the local activity of foreign Multinational Enterprises (MNEs) affiliates for a country development with some arguing for a positive effect (e.g. Caves 1974; Findlay, 1978; Blomstrom,1989) other like Hymer, (1970) stressing the relevance of the negative consequences. According to Brunner (2006) MNE is a controversial phenomenon whose protagonist believe it is a threat to economic sovereignty of developing nations, hinders development of self-reliance and promote materialism. Cantwell and Dunning (1986) believe that the impact of the foreign presence depends on a set of conditions, and that it may turn both virtuous and vicious circles of technological development in the location affected by foreign MNEs activity. Increasingly, however, in practice, many developing countries are learning to live with the MNEs and to devise control systems which increase the benefits flowing from their operations

Multinational Enterprise's have been defined differently by different scholars. Among the notable definition, Dunning, (1973) defined a Multinational as an enterprise which owns and controls income generating assets in more than one country. United Nations in 1973 looked at MNEs as an enterprise which control assets - factories, mines, sales offices and the like - in two or more countries. Lalnunmawia (2010) defined Multinational Enterprises as a huge industrial organization that have a wide network of branches and subsidiaries spread over a number of countries. Multinational Enterprises enter into joint venture with companies in another country and there may be agreement among companies of different countries in respect of division of production, market, etc. Developing countries are interested in attracting foreign capital since domestically sourced funds are often insufficient to finance their investment needs (Drabek and Payne, 2001). Multinational Enterprises are increasingly seen as global networks of firms, and one of the main characteristics of these networks is the creation, diffusion and commercialization of technological innovations (Dunning and Gugler, 1994). It is also noted that MNEs are not in the economic development business and are least interested in is the diffusion of their proprietary technology and spillovers depend on the absorptive capacity of domestic firms. It also depends on structure of the local resources and capabilities 
of the host country, as well as the macro-economic and organizational policies pursued by governments (Dunning and Narula, 1996).

\section{Location Theory of International Investment}

THEORETICAL LITERATURE REVIEW

The location theory is of two kind; "supply oriented location theory" and "demand oriented location theory". The supply oriented location theory explains that production takes place where the factor costs for production (including distribution) are the lowest (Dunning, 1973). The demand oriented location theory asserts that the location of a firm is governed by the location of its market and competitors (Dunning, 1973). The two theories put together give rise to four main locational factors; raw materials, cheap labor, protected and untapped markets, and transportation costs are believed to give rise to the emergence of MNEs (Buckley, 1985). This approach provide valuable insights as to geographical distributions of MNEs, it fell short to explain "how it was that foreign owned firms could outcompete domestic firms in supplying their own market" (Dunning, 1979), neither did it give any hint about the origin countries of MNEs.

\section{The Aliber Theory}

Aliber (1970) hypothesized that it is the financial market which enables firms to have advantages over host country firms and applicable to all firms whose assets and borrowing are based in selected currencies. He reasoned that MNEs tend to flow from strong currency areas to weak currency areas. The critics of this theory argued that while the view is compatible with the early post-war American domination, it gave no account of the rise of European and Japanese MNEs (Buckley and Casson, 1976; Ragazzi, 1973). Ragazzi 1973 pointed out that "net FDI of the UK increased rapidly at a time when sterling was weak". In defense, Aliber (1983) attributed the upsurge of FDI from Japan and Europe to the decline of "market values" of US firms relative to the market value of firms headquartered abroad. Another criticism pinpointed an important issue that many MNEs raise much of their funds for investment in host countries and currencies where the investments take place and financial capital is not the most important component of MNEs (Hennart, 1982). However, Cantwell (1991) sees the theory as giving useful insights about the "timing" of FDI and "take-overs" of MNEs which move into an unrelated business sector.

\section{Hymer-Kindleberger Theory}

The theory is also known as monopolistic or oligopolistic power, structural market imperfection, market power and industrial organization theory. In his theory Hymer tried to answer three questions (i) why do firms go abroad, (ii) how are they able to survive in foreign market in which they bear a the initial cost (iii) why do they want to retain control and ownership. Hymer (1976) then proposes three explanations for FDI: (i) Foreign investors seek control to ensure the safety of their investment; (ii) the investor seeks to remove competition or to use certain skills and capabilities in a more profitable way; (iii) the controlling and the controlled firm may have complementary assets and skills which again may better be exploited through common ownership than through market transactions in the presence of imperfect markets. FDI is consequently a rent-seeking activity, or, in other words, an investor does not engage in FDI for higher interest rates but for higher profits.

In the presence of market failures, Hymer argues, collusion in the form of common ownership might provide an important motivation for FDI (Hymer, 1976). According to the market structure, horizontal collusion may indeed be profitable if the firm can demand higher prices after the merger. Vertical collusion may be advantageous if the firms can elude a sequential monopoly problem that is the problem of the double margin (Hymer, 1976). Accordingly, FDI is an instrument to avoid competition and will lead to inefficient market structures. Hymer considered the removal of competition as the key factor FDI, and his contributions induced 
many scholars to write critically about the activities of multinational firms. However, latter scholars have questioned this pessimistic view.

\section{The eclectic (OLI) paradigm Theory}

This theory was proposed by Dunning in 1993 and seeks to offer a general framework for determining the extent and patterns of both foreign owned production undertaken by a country's own enterprises and also that of domestic production owned by foreign enterprises. According to this paradigm, the extent and pattern of international production is determined by three factors (Dunning, 2001). The first factor is ownership advantage (0) as MNEs wishes to place in a particularly advantageous location which has a comparative advantage in an activity or most favourable. Dunning (1998) argues that the locational preferences have changed as regional integration and sinking spatial transaction costs have increasingly forced MNEs to engage in international production, enhancing the international division of labour (Dunning, 1998). The second factor is interest in locating activities abroad (L). Multinationals set abroad to tap into the ownership advantages as consumers have a strong bias for national products, and domestic firms have better access to information about their country and government interventions are likely to discriminate foreigners, and foreigners face the exchange rate risk (Hymer, 1976). The third factor is internalization advantage (I) that explains that MNE chooses to internalize the operations, if it is easier to exploit the ownership advantages within a company, or if internalization can better prevent the dissipation of the advantage. (Dunning, 1993).

The Eclectic theory relies on two kinds of market imperfections (failure). The first is that the structural market failure which discriminates between firms in their ability to gain and sustain control over property rights or to govern multiple geographically dispersed value-added activities. The second is that of the failure of intermediate product markets to transact goods and services at a lower net cost than those which a hierarchy might have to incur. Dunning states that the assumption of the existence of perfect markets contributes to the failure of the factor endowment approach to explain international production (completely or partially). In neo-classical trade theory, this leads to all sorts of restrictive assumptions, such as atomistic competition, equality of production functions, the absence of risk and uncertainty and implicitly at least, that technology is a free and instantaneously transferable good between firms and countries.

The eclectic paradigm has been extended to a dynamic model: the investment development path. Its basic assumption is that the configuration of the OLI advantages changes as a country moves up the stages of development (Dunning, 2001). Outward and inward FDI are hence determined by the stage of development and at the same time determine the stage of development. According to the Eclectic theory, three reasons reflect the inability of the market to organize transaction in optimal way: the buyers and sellers do not enter the market with complete (or symmetrical) information or perfect certainty about the consequences of the transactions they are undertaking (Dunning, 2002). The market cannot take account of the benefits and costs that arise as a result of a particular transaction, but which are external to that transaction. The demand of a particular product, while infinitely elastic, is insufficiently large to enable the producing firm fully to capture the economies of size, scope and geographical diversification. There is an inevitable trade-off between the overall costs of a set of value-added activities and the opportunity they offer for emerging economies (Galbraith and Kay, 1986). The outcome of the trade-off between the Multinationals and the local economy is eminent through the intangible firm specific advantages transferred by the firms at low cost. These firm specific advantages are namely technology and knowledge spillover to the domestic 
firms. This tradeoff, among other pertinent elements of Eclectic theory, is what makes it duly applicable in this study.

\section{Absorptive Capacity}

The concept absorptive capacity first emerged as significant in the 1980s in the field of organization learning. (Vega, Gracia and Ignacio, 2007). There is no unanimity among scholars on the concept of absorptive capacity; infact there are as many definitions of the concept as there are scholars. Cohen and Levinthal (1990) defined absorptive capacity as the ability to recognize the value of new external information, assimilate it, and apply it to commercial ends.

A review of existing theoretical literature has identified four dimensions of absorptive capacity. These are acquisition, assimilation, transformation, and exploitation. According to Zahra and George (2002) the first two dimensions are from potential absorptive capacity, the latter two are realized absorptive capacity. Knowledge acquisition is the firm's capability to identify relevant external information over the total amount of information that surrounds the firm. Acquisition is defined as the ability to recognize, value, and acquire external knowledge that is critical to a firm's operations (Zahra \& George, 2002). According to Dyer and Singh (1998) the ability to evaluate and utilize outside knowledge is largely a function of the level of prior related knowledge. Prior knowledge confers an ability to recognize the value of new information, to assimilate it and to apply it to commercial ends Knowledge assimilation refers to the firm's ability to absorb external knowledge. Zahra and George (2002) defined it as a firm's routines and processes that allow it to understand, analyze, and interpret information from external sources. This perspective allows employees to understand and take advantage of external information in discovering new suppliers, new methods and techniques and new products and services.

The knowledge transformation is the firm's ability to modify and adapt external knowledge and combine it with existing and internally generated knowledge (Zahra \& George, 2002). It refers to knowledge internalization in order to codify a process, to question employee's regards to the way of working in other companies, to improve processes through, discover new solutions, to go faster or adapt to environmental and technological evolutions. Transformation can be achieved by adding or deleting knowledge, or interpreting existing knowledge in a different way. Transformation scale measures employee's involvement concerning the improvement of some processes or way of doing things in their company (Chauvet, 2003).

The last element is knowledge exploitation which refers to the routines that allow firms to refine, extend, and leverage existing competences or create new ones by incorporating acquired and transformed knowledge into its operations (Zahra \& George, 2002). It can also refer to a firm's ability to apply new external knowledge commercially to achieve organizational objectives (Lane \& Lubatkin, 1998). Exploitation is an organization capability that allows firm's to refine, extend, and leverage existing competences or to create new ones by incorporating acquired and transformed knowledge into its operations. This requires that the knowledge is shared by a larger audience within the organization than the people who initially participated which is peripheral learning. Social integration mechanism can facilitate the sharing and eventual exploitation of knowledge. (Zahra \& George, 2002). The results of absorptive capacity are very hard to copy which makes the process of absorption a competitive advantage in and of itself (Peteraf, 1993). Business makes investments that increase their ability to absorb and the more externalities that are in their environment, the greater the incentive to invest in improving the capacity for absorption (Cohen a\& Levinthal, 1990). Foreign Direct Investments increases competition allowing local businesses to absorb technological novelties and effective processes from foreign firms thus raise their productivity (Rugman \& Verbeke, 2001). Taking advantage of the spillover from FDI depends on the capacity to absorb them (Cohen \& Levinthal, 1990). 


\section{Studies on Absorptive Capacity}

\section{EMPIRICAL LITERATURE REVIEW}

Pedro, Jorge and Jose (2014), identified the effects of research and development activities and expenditures, research and development results, the internal organization of innovation, the external links for innovation, the quality of human capital, family management, and the complexity of businesses and market concentration. They found that research and development activity boost the generation of new knowledge and absorptive capacity from MNEs. Research and development activities were found to have the most positive effect while externalized research and development activities have a negative impact. They also found a negative link between public funding and absorptive capacity from MNEs. Their result is consistent with the fact that public financing of research and development is less effective than private funding (Griliches, 1986) and supports the notion that the companies that manage to find private financial resources are more capable of absorbing spillovers from MNEs.

Pedro, Jorge and Jose (2014) also found complexity and production-process innovations as other factors determining absorptive capacity. Complex and innovative production processes makes more and better tools available for absorbing the spillovers from MNEs. Multinational Enterprises are usually more complex, they have innovative production processes than local companies, and this helps them absorb from similarly complex, innovative foreign firms. A domestic firm with a complex, innovative production processes has capacity to apply and produce knowledge and this capacity shows up in the absorptive capacity of external knowledge from MNEs.

The study by Pedro, Jorge and Jose (2014) identified several constraints such as outsourcing and distance may affect absorptive capacity depending on, for example, the type of activity or the communication flow. Second, they argued that the study can be extended to include geographical location of foreign firms relative to local companies. Distance determinants such as culture, physical location, or institutional differences may influence absorptive capacity from MNEs. Kneller (2005) examines how technology transfer is affected by absorptive capacity (measured by human capital and research and development) in a panel of manufacturing industries in 12 OECD countries which covers the period 1972 to 1992 . The study finds evidence that human capital facilitates diffusion of foreign technology. With regard to research and development, Kneller (2005) finds that research and development plays an important role in innovation but it plays a role in facilitating technology adoption only in small and less research and development intensive OECD countries. He argued that for smaller, less research and development intensive countries, research and development might play a more important role in absorbing technology from abroad than in the creation of new technology.

Kinoshita (2000) uses foreign ownership and finds no evidence that absorptive capacity facilitates technology transfer through this channel. Hu, Jefferson and Jinchang (2005) measures access to foreign technology as technology purchased through licensing agreements from foreign firms and they find that $R \& D$ enhances firm's absorptive capacity and thus facilitates technology transfer. Mayer (2001) studied the role of human capital in facilitating technology transfer through imports of machinery and equipment in 53 developing countries between 1970 and 1990. The study adopted a model in which total factor productivity depends on technology transferred through imports of machinery and equipment, the stock of human capital, and technology transferred facilitated by the absorptive capacity of the country, represented by an interaction between these two variables. Human capital is measured as the average number of years of schooling in population aged 15 or above. Technology transfer through imports of machinery and equipment is measured as average ratio of imports of machinery and equipment to the GDP. Mayer (2001) finds a positive and statistically 
significant impact of the interaction between human capital and machinery imports, suggesting that human capital plays an important role in assimilating foreign technology.

Kinoshita (2000) finds that investment in research and development has no impact on technology transfer through foreign ownership. Damijan, Knell, Majcen and Rojec (2003) find that investment in research and development facilitates technology transfer through horizontal spillovers only in two countries (Slovakia and Hungary), and it actually hinders horizontal spillovers in Estonia and Latvia and has an insignificant effect in the other transition countries. Koymen and Sayek (2009) find that the human capital has a negative effect on the spillovers through backward linkages and that the horizontal FDI spillovers and forward FDI spillovers on the TFP level of domestic firms are not affected by the human capital level of these firms. Hu, Jefferson and Jinchang (2005) find evidence consistent with the hypothesis that research and development enhances firm's absorptive capacity and thus facilitates the adoption of technology purchased through licensing agreements from foreign firms. Girma, Gong and Gorg (2009) find that Chinese firms that invest in own research and development and those that provide training for their employees benefit more from inward FDI in the sector than firms that do not.

Kneller, Pantea and Upward (2010) examined whether investment in research and development, training and employees education increases the probability of firms' participation in supplying MNEs, exporting and becoming foreign affiliates. If the domestic firms are selected by their foreign partners to become affiliates or suppliers based on their absorptive capacity, then the firms selected will have the necessary absorptive capacity to implement the technology transferred. The results suggest that past absorptive capacity, measured as share of workforce with tertiary education, is positively and significantly correlated with supplying MNEs, exporting and foreign ownership. The magnitude of the effect on workforce education in 2001 on the participation in international activities in 2004 is similar to the effect reported for contemporary workforce education. Firms that had high levels of absorptive capacity, in terms of workforce education, are significantly more likely to become foreign affiliates, MNEs suppliers or exporters.

\section{Studies on research and development activities and absorptive capacity}

The intensity of research and development, total intangible assets per worker, and technological gaps determine how well local firms absorb MNEs spillover (Liu, Siler, Wang \& Wei (2000) and Dimelis, (2005)). According to Nieto and Quevedo, (2005) businesses do not tend to undertake research and development activities if they can simply glean technological knowledge from outside sources. In this way, a capacity for absorption is relevant in acquiring new technology that spillover from MNEs, and it therefore affects the productivity of local firms (Caves, 1974). The absorptive capacity of an enterprise, however, comes through acquiring, assimilating, and propagating new knowledge gleaned from outside the firm; more overall research and development in an industry enhances it (Liao, Welsh \& Stoica, 2003). Spending in research and development creates competitive advantages by encouraging companies to absorb technological spillovers from external sources (Veugelers, 1997). Research and development expenditures imply that companies are willing to assimilate routines and processes, thereby increasing their stock of knowledge and improving their capacity for absorption (Mowery, Oxley, and Silverman, 1996). Overall then, we expect research and development expenditures to increase absorptive capacity of spillovers from MNEs at the firm level. Pedro, Jorge and Jose (2014) in their study on absorptive capacity from foreign direct investment in Spanish Manufacturing firms found that research and development activities boost the generation of new knowledge and absorption capacity from MNEs. 


\section{Studies on the internal and external organization and absorptive capacity}

Internal organization of innovation variable facilitates transfer of information among departments and this increase the capacity for absorption (Van den Bosch et al., 1999). To maximize this communication, the firm must design flexible formal and informal organizational structures (Liao et al.,2003), it must create multi-disciplinary teams and close links between the research and development department and other departments (Gupta and Govindarajan, 2000 and Meeus, M.T.H. Oerlemans, L.A.G. and Hage J., 2001), and it must encourage innovation (Jones and Craven, 2001). A culture of innovation stimulates knowledge, improves execution, has effective problem resolution, and encourages suggestions and continuous learning, because these things increase the capacity for absorption (Lenox and King, 2004). Also, the formal existence of a research and development department in a firm increases its absorptive capacity (Cassiman and Veugelers, 2002). Companies with strong, structured, internal research and development activities glean results from external sources more easily (Lowe and Taylor, 1998). External research and development activities also increase absorptive capacity, but only if an organization already has absorptive capacity (Griffith, Redding and Reenen, 2004).

There is some evidence that externalized research and development activities strengthen the capacity to absorb spillovers from foreign companies (Lowe and Taylor, 1998). Firms are more likely to outsource research and development when they are less efficient in research and development than supplier companies are. Whereas the supplier of research and development get economies doing research and development, they have no specific assets for research and development and their research and development is relatively standardized (Pedro, Jorge and Jose 2014).

Park and Ghauri (2011) maintain that collaborative support from knowledge transferors is a prerequisite to help organizations to absorb technological capabilities. According to Lei and Hitt (1995) not all firm relationships improve absorptive capacity, infact, inter-organizational agreements for acquiring external technology might reduce absorptive capacity. Financial resources affect the capacity to absorb, because they provide the means for carrying out research and development activities, for reaching cooperation agreements with other firms and institutions, and for employing suitably trained staff, among other things (Kamien and Zang, 2000). Publicly funded research and development produces different results (David, Hall, and Toole, 2000). Some studies find positive effects from publicly funding research and development (Aerts and Schmidt, 2008) and others find insignificant or negative effects (Lach, 2002). However, publicly funding research and development is less effective than privately funding it (Griliches, 1986).

National governments may attempt to attract MNEs, principally because they hope it will lead to positive spillovers for local businesses (Narula and Dunning, 2000). Further, these governments may adopt measures that favor innovation in local firms so that they will be in a position to absorb knowledge from foreign enterprises. Some of these decisions may include stimulating the entry of MNEs, reducing obstacles to MNEs, supporting investments, offering tax incentives, adjusting patent regulation among others (Dunning and Gugler, 2008).

\section{Studies on the quality of human resource and absorptive capacity}

The behavioral science literature suggests that both ability and motivation is of importance for individual behavior and few would question the assertion that "if individuals possess the prerequisite ability to learn performance is likely be poor if motivation is low or absent" (Baldwin, Magjuka, \& Loher, 1991). Campbell (1976) noted that in industrial and organizational psychology performance is a function of the interaction between ability and 
motivation. Further, empirical evidence supports rather strongly that there is an interactive, not additive, effect of ability and motivation on performance (O'Reilly \& Chatman, 1994). Applying the concept of the interactive effect of ability and motivation on the issue of knowledge transfer, we expect that a higher rating in knowledge acquired will be achieved, if knowledge receivers have both ability and motivation to absorb new external knowledge.

Human capital is necessary for indigenous firm's to absorb and implement new technologies. According to Driffield and Taylor (2002) the demand for skilled workers increases when firms use superior technology as the development and effective use of technology requires human capital. Human capital is therefore increasingly considered a major constraint in implementing globally competitive strategies (Smale, 2004). Successful companies treat employees as permanent; employees are trained on an ongoing basis in order to improve their productivity (Porter, 1990). According to Lall, (2001) lacking worker skills is a major reason for slow adoption of new technologies.

Positive productivity spillovers can occur through movement of highly skilled staff from MNE's to domestic firms (Blomström \& Kokko, 1998). MNEs have been found to generally produce with higher capital intensity (Blonigen \& Slaughter, 2001). As the degree of human skills required is generally higher in capital intensive production, we may assume that MNEs will provide more and better training for their staff. There is also extensive evidence that investments in employee training pay off in terms of enhancing the human capital of the firm and generally a positive relationship has been established between employee training and organizational performance (Delaney \& Huselid, 1996). "The effectiveness of even highly skilled employees will be limited if they are not motivated to perform" (Huselid, 1995). Previous research has shown that employees are more motivated when they know what is going on in the firm. Sharing of information on, for example, strategy and company performance conveys to the employees that they are trusted. Further, it is important that employees know what is going on in a firm so that they can use the knowledge that resides in the firm to its fullest potential (Pfeffer, 1998).

\section{Studies on competitive advantage}

The concept of competitive advantage seeks to capture the elements that explain the success of the firms and analysis how enterprises manages the totality of their competences to achieve prosperity or profits. Competitiveness for the purpose of this study conceptualized to mean productivity and innovation. The two constructs are illustrated below;

\section{Studies on productivity and competitive advantage}

Productivity arises from knowledge spillover from MNEs. Spillover from MNEs arises from transactions outside specific markets, in which resources and particularly knowledge spread without any contractual relationship (Meyer, 2004). Spillover within an industry is improvements in productivity that local firms learn from foreign companies operating in the same sector. Many empirical studies about inward FDI ask whether "domestic firms really benefit from foreign direct investment". Aitken, Harrison and Hanson (1999), for instance, discover that FDI has a small negative effect on the productivity of domestic firms in Venezuela. They point out that while domestic firms benefit from positive spillovers, foreign firms draw demand from domestic firms and thereby force the domestic firms to spread their fixed costs over a smaller market and this might reduce their productivity of domestic firms ( Aitken, Harrison and Hanson 1999). Gorg and Strobl (2001) investigated empirically the effects of foreign direct investment (FDI) on the productivity performance of domestic firms in three emerging economies of Central and Eastern Europe, Bulgaria, Romania and Poland. They found no evidence of positive spillovers to domestic firms on average. In contrast, on average there are negative spillovers to domestic firms in Bulgaria and Romania, while there are no 
spillovers to domestic firms in Poland. This suggests a negative competition effect that dominates a positive technology effect.

Governments often promote inward foreign investment to encourage technology 'spillovers' from foreign to domestic firms. Konings and Jozef (2001) investigated the effects of Foreign Direct Investment on Domestic Firms in using a panel data on Venezuelan plants. They found out that foreign investment negatively affects the productivity of domestically owned plants. The net impact of foreign investment, taking into account these two offsetting effects, is quite small. Using cross-sector industry data Blomstrom and Wolff (1994) find that a foreign presence helps domestic firms to achieve higher levels of productivity. Haddad and Harrison (1989) do not detect any spillover effect in a sample of Moroccan firms.

\section{Studies on Innovation and competitive advantage}

According to Rogers (1995), an innovation is "an idea, practice or object that is perceived as new by an individual or other unit of adoption". The innovation literature includes many studies of the creation, diffusion and adoption of a variety of administrative system applications to organizational settings. The diffusion of an innovation concerns "the process by which an innovation is communicated through certain channels over time among the members of a social system" (Rogers, 1995). These ideas bolster the argument that MNEs may have different and more innovative systems relative to their domestic counterparts.

A knowledge-based competitive advantage is, in essence, innovative in the way that it develops through the creation of a new product, service, process or structure. According to Gurteen, 1998 knowledge based firms will not only quickly respond to customers' needs, but also actively shape their expectations for future products and services. For Liu and White (1997), absorptive capacity is a predictor of innovative output: Innovation is driven by synergy through investments in sources of new knowledge and in absorptive capacity. Moreover, knowledge embedded in the interactions of people, tools, and tasks provides a basis for competitive advantage in firms (Argote and Ingram, 2000).

\section{Proposed Conceptual Framework}

The figure i below provide a sequence of the relationships that the researcher conceptualized in term of how competitive advantage of domestic firms can be achieved through knowledge spillover from MNEs. The model proposes that MNEs presence provide a source of knowledge that result to absorption and transfer of knowledge to domestic firms.

Absorptive capacity is conceptualized as the intervening variable in the relationship between MNEs presence and competitive advantage. It is a variable that help explain how local firms are able to assimilate new knowledge and then exploit it for competitive advantage. It is conceptualized as research and development activities, internal and external organization of research and quality of human capital. The distance is conceptualized as moderating the relationship between MNEs presence and competitive advantage and is operationalized as culture, physical location and institutional difference. The competitive advantage was the dependent variables and was operationalized as productivity and innovation. 
Figure i. Conceptual Framework

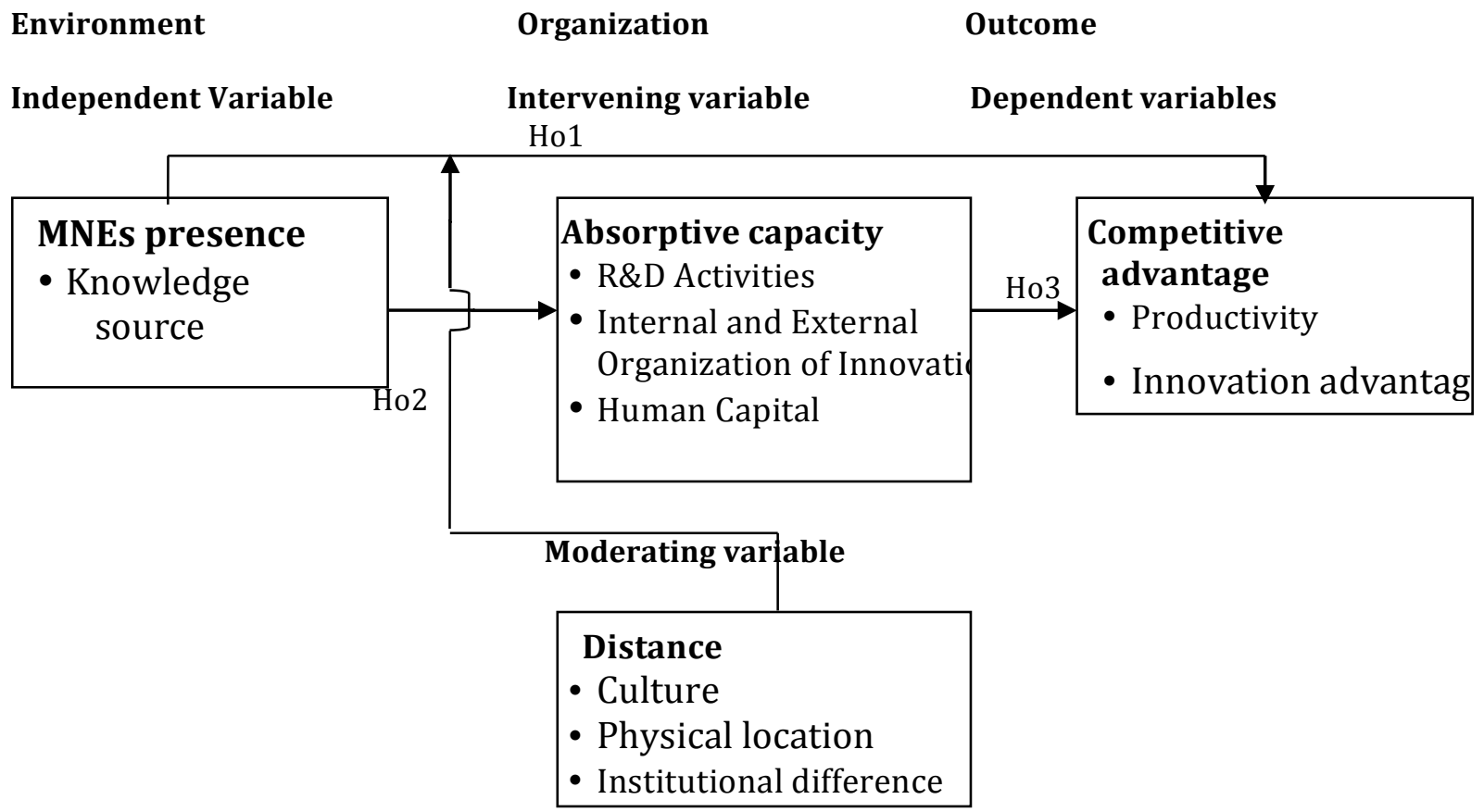

Source: researcher conceptualization 2015.

In line with our model we posit that;

Ho1: the greater the firm exposure to knowledge source, the greater the firms competitive advantage.

Ho2: distance has no statistically significant effect on the relationship between the firm's exposures to knowledge source and competitive advantage.

Ho3: the greater a firm's absorptive capacity, the greater a firm will acquire a competitive advantage, taking into consideration the indirect influence of distance.

\section{CONCLUSION}

The general and empirical literature review of Multinational Enterprises presence and competitive advantage of firms shows that MNEs presence enhances the competitiveness of firms. MNEs presence facilitates transfer of knowledge to domestic firms which in turn achieve competitive advantage. This transfer is made possible by the existence of the absorptive capacity among the firms. The reviewed literature support the argument that the greater a firm's exposure to knowledge sources, the greater the firm will acquire the competitive advantage. In addition the higher the firm's absorptive capacity, the more effective the transfer of knowledge from the MNEs which in turn leads to more competitiveness.

Given the fact that absorptive capacity is a powerful tool to upgrade the efficiency of the firms, we argue that the existence of absorptive capacity may allow firms to benefit more from MNEs spillovers and thus get higher results in terms of productivity and innovation increase.

\section{Limitations of the study}

Like all research, the present study has limitations. Similar to other independent study, no primary data was collected. The study relied on existing literature and it is more of a conceptual study. We recommend that future studies collect primary data on the study variables so as to arrive at more conclusive results. Finally, there are other factors potentially influencing the competitiveness of the firms. While this study makes important contributions to our understanding of the relationship between multinational enterprises, absorptive capacity and competitive advantage, this study is clearly only a first step and additional research is needed on this issue. 


\section{References}

Aerts, K., Schmidt, T. (2008) 'Two for the Price of One? Additionality Effects of R\&D Subsidies: A Comparison Between Flanders and Germany', Research Policy, 37 (5):806-822.

Aliber, R. Z. (1970), "A theory of direct foreign investment", in C. P. Kindleberger (ed.) The International Firm. Cambridge, Mass: MIT Press.

Aitken, B., A. Harrison and G.D. Hanson (1999). Do Domestic Firms Benefit from Direct Foreign Investment? Evidence from Venezuela. American Economic Review, 89/3, 605-618.

Argote, L. and Ingram, P. (2000), "Knowledge transfer : a basis for competitive advantage in firms", Organizational Behavior and Human Decision Processes, Vol. 82, N․ 1.

Blomstrom M \& Kokko, A. (1998). Multinational Corporations and Spillovers. Journal of Economic Surveys, 12/2.

Blomström, M. And E. Wolff (1994), "Multinational corporations and productivity convergence in Mexico", in W. Baumol, R. Nelson and E. Wolff (eds.).

Bloningen, B. A. \& Slaughter, M. J. (2001).Foreign-Affiliate Activity and U.S. Skill Upgrading. The Review of Economics and Statistics, 83/2.

Buckley, P. J. (1985) "A critical view of theories of the multinational enterprise", in P. J. Buckley and M. Casson (eds.), , The Economic Theory of Multinational Enterprise. London: The Macmillan Press.

Buckley, P. J. and M. C. Casson (1976), The Future of Multinational Enterprise. London: The Macmillan Press.

Campbell, John P. 1976. Motivation in Industrial and Organizational Psychology. In Marvin D. Dunnette (ed.) Handbook of Indusrial and Organizational Psychology: 63-130. Chicago: Rand McNally

Caves, R. E. (1974). Multinational firms, competition, and productivity in host country markets, Economica, 41.

Chauvet, Vincent (2003), Absorptive capacity and knowledge transfer Propensity: towards the obtaining of a competitive advantage. IAE Aix-en-Provence, Clos Guiot - BP 33, 13540 Puyricard

Cohen, Wesley M., Levinthal, Daniel A. (1990) Absorptive Capacity: A New Perspective on Learning and Innovation. Administrative Science Quarterly. Ithaca: Vol. 35, Iss. 1.

Damijan, J. P., Knell, M., Majcen B. and Rojec M. (2003). "Technology Transfer through FDI in Top-10 Transition Countries: How Important are Direct Effects, Horizontal and Vertical Spillovers?," William Davidson Institute Working Papers Series 549, William Davidson Institute.

Driffield, N. \& Taylor, K. (2002). Spillovers from FDI and skill structures of host-country firms. Discussion Papers in Economics 02/4, Department of Economics, University of Leicester.

Dunning, J. H. (1979), "Explaining changing patterns of international production: a search for the eclectic theory", Oxford Bulletin of Economics and Statistics, 161.

Dunning, J. H. (1993). The globalization of business, London: Routledge.

Dunning, J. H. \& Gugler, P. (1994). Technology Based Cross-border Alliances. In D. J. Jeremy (ed.), Technology Transfer and Business Enterprise, Cheltenham, UK: Edward Elgar.

Dunning, J.H. (1998) 'Location and the Multinational Enterprise: A Neglected Factor?',Journal of International Business Studies, 29(1), 45-66.

Dunning, J. H. (2001). The Eclectic (OLI) Paradigm of International Production: Past, Present and Future. International Journal of the Economics of Business. 8/2.

Dunning, J. H. \& Narula, R. (1996). The Investment Development Path Revisited: Some Emerging Issues. In J. H. Dunning and R. Narula (eds), Foreign Direct Investment and Governments: Catalysts for Economic Restructuring, London: Routledge 67.

Findlay, Ronald (1978): "Relative Backwardness, Direct Foreign Investment, and the Transfer of Technology: A simple dynamic model". Quarterly Journal ofEconomics, Vol. 92, pp. 1-16.

Girma, S., Gong, Y. and Görg, H. (2009) "What Determines Innovation Activity in Chinese State-owned Enterprises? The Role of Foreign Direct Investment", World Development, vol. 37(4).

Görg, H. \& Strobl, E. (2001). Multinational Companies and Productivity Spillovers: A Meta-Analysis. The Economic Journal, 111.

Griffith, R., Redding, S. and Van Reenen, J.(2004) "Mapping the Two Faces of R\&D: Productivity Growth in a Panel of OECD Industries," The Review of Economics and Statistics, vol. 86 (4).

Griliches Z. (1986), Productivity, R\&D and basic research at the firm level in the 1970s, American Economic Review, 76, pp. 141-154

Gupta, A. K. and Govindarajan, V. (2000), "Knowledge management's social dimension: lessons from Nucor Steel”, Sloan Management Review. 
Hymer S (1970). The efficiency (contradictions) of Multinational Corporations. American Economic Review 60:441-448.

Hu, A. G. H., Jefferson, G. H. and Jinchang, Q. (2005), "R\&D and Technology Transfer: Firm-Level Evidence from Chinese Industry," The Review of Economics and Statistics, vol. 87(4).

Huselid, M. (1995) 'The impact of human resource management practices on turnover, productivity, and corporate financial performance', Academy of Management Journal 38: 635-672.

Hymer, S. (1976). The International Operations of National Firms, Ph.D. Thesis, Cambridege, MA: MIT Press.

Kinoshita (2000), "R\&D and Technology Spillovers through FDI: Innovation and Absorptive Capacity", CERGE-EI Working Papers 163, The Center for Economic Research and Graduate Education - Economic Institute.

Kneller, R. (2005). "Frontier Technology, Absorptive Capacity and Distance," Oxford Bulletin of Economics and Statistics, vol. 67(1), pp. 1-23.

Kneller R, Pantea, Upward R, (2010), Does Absorptive Capacity Affect Who Benefits from International Technology Transfer?

Koymen, S. and Sayek, S. (2009), "The Role of Human Capital in Productivity Spillovers from FDI: An Empirical Analysis on Turkish Firms".

Lach S (2002), Do R\&D subsidies stimulate or displace private R\&D evidence from Israel, Journal of Industrial Economy, 50 (4) pp. 369-390

Lall, S. (2001).Competitiveness, Technology and Skills. Cheltenham: Edward Elgar.

Lane, P. J. and Lubatkin, M. (1998), "Relative absorptive capacity and inter-organizational learning", Strategic Management Journal, Vol. 19.

Liao, Jianwen, Harold Welsch and Michael Stoica (2003), Organizational absorptive capacity and responsiveness: An empirical investigation of growth-oriented SMEs, Entrepreneurship Theory and Practice 23, 63-86.

Liu, X., Siler, P., Wang, C., \& Wei, Y. (2000). Productivity spillovers from foreign direct investment: Evidence from UK industry level panel data. Journal of International Business Studies, 31(3): 407-425

Liu, Xielin and Steven R. White (1997), The relative contributions of foreign technology and domestic inputs to innovation in Chinese manufacturing industries, Technovation 17, 119-25.

Malmberg, A. and Sölvell, Ö (2002) 'Does Foreign Ownership Matter? Subsidiary Impact on Local Clusters', in Havila, V., Forsgren, M. and Håkansson, H., eds., Critical Perspectives on Internationalisation, International Business and Management Series, Amsterdam: Pergamon, 59-78.

Meeus, M.T.H. Oerlemans, L.A.G. Hage J., (2001), Patterns of interactive learning in a high-tech region! Organization Studies, 22 (1), pp. 145-172

Mayer, J. (2001), “Technology Diffusion, Human Capital and Economic Growth In Developing Countries,” UNCTAD Discussion Papers 154, United Nations Conference on Trade and Development.

K. Meyer (2004), Perspectives on multinational enterprises in emerging economies, Journal of International Business Studies, 35 pp. 259-276.

Mowery, David C., Joanne E. Oxley and Brian S. Silverman (1996), Strategic alliances and interfirm knowledge transfer, Strategic Management Journal 17, 77-91.

Narula R., Dunning J.H. (2000), Industrial development, globalization and multinational enterprises: new realities for developing countries, Oxford Development Studies, 28 (2) pp. 141-167

Nieto, Mariano and Pilar Quevedo (2005), Absorptive capacity, technological opportunity, knowledge spillovers, and innovative effort, Technovation 25, 1141-57.

O'Reilly, C.A. and Chatman, J.A. (1994) 'Working smarter and harder: a longitudinal study of managerial success', Administrative Science Quarterly 39: 603-627.|

Park B.I., Ghauri P.N (2011). Key factors affecting acquisition of technological capabilities from foreign acquiring firms by small and medium sized local firms, Journal of World Business, 46 pp. 116-125.

Pedro S S, Jorge R M and Jose, G(2014),Absorptive capacity from foreign direct investment in Spanish manufacturing firms, International Business Review, Vol.23, Issue 2014.

Peteraf, M. A. (1993), "The cornerstones of competitive advantage: a resource-based view", Strategic Management Journal, Vol. 14.

Pfeffer, J. (1998) The Human Equation: Building Profits by Putting People First, Harvard Business Press: Boston. Porter, M. E. (1990), The Competitive Advantage of Nations. Boston MA: Macmillan.

Prahald C.K and Hamel Gary (1990), “The Core Competence of the Corporation” Harvard Business Review, MayJune, 1990 
Ragazzi, G. (1973), "Theories of the determinants of direct foreign investment", IMF Staff Papers, 20 (July).

Reich, R. (1991). The work of nations: preparing ourselves for 21st-century capitalism. London, UK: Simon \& Schuster.

Rogers, E., Diffusion of innovations, the Free Press: New York. 1995.

Rugman A.M., Verbeke A. (2001), Subsidiary specific advantages in multinational enterprises, Strategic Management Journal, 22, pp. 237-250.

Rumelt, R.P., Schendel, D., \& Teece, D. J. (1991).Strategic Management and Economics. Strategic management Journal, 12:5-29.

Smale, A. (2004). HRM integration in the Global Firm: A Knowledge Transfer Perspective. Paper presented at the EIBA Conference 2004.

Van den Bosch, Frans A. J., Henk W. Volberda and Michiel de Boer (1999), Coevolution of firm absorptive capacity and knowledge environment: Organizational forms and combinative capabilities, Organization Science 10.

Veugelers R., (1997), Internal R\&D expenditures and external technology sourcing, Research Policy, 26 (3), pp. 305-315

Wernerfelt, B. (1984), A resource-based view of the firm, Strategic Management Journal, Vol. 5, pp. 171-180.

Zahra, S.A. and George, G. (2002), "Absorptive capacity: A review, reconceptualization, and extension", The Academy of Management review, Vol. 27. 